\title{
A NEW SPECIES OF LAENNECIA (ASTERACEAE: ASTEREAE) FROM CHIHUAHUA, MÉXICO
}

\author{
Guy L. Nesom' \& Joseph E. Laferrière ${ }^{2}$ \\ ${ }^{\prime}$ Department of Botany, University of Texas, Austin, Texas 78713 U.S.A. \\ and \\ ${ }^{2}$ Department of Ecology and Evolutionary Biology, University of Arizona, \\ Tucson, Arizona 85721 U.S.A.
}

\section{ABSTRACT}

A new species, Laennecia pimana Nesom \& Laferriére, is described. It apparently is narrowly endemic to the Sierra Madre Occidental of west central Chihuahua, México, and is most closely related to two other endemics of the same region, Erigeron (Laennecia) eriophyllus A. Gray and an as yet undescribed species of Laennecia. Laennecia pimana differs from these species by its eligulate pistillate corollas.

\section{RESUMEN}

Una nueva especie, Laennecia pimana Nesom \& Laferriére, se describe. Posee un distribución muy restringida en la Sierra Madre Occidental del oeste de Chihuahua, México, y esta mas emparentada con otras especies endémicas de la misma región, Erigeron (Laennecia) eriophyllus A. Gray y una otra nueva especie de Laennecia. Laennecia pimana se diferencia de las anteriores por las corolas pistiladas eliguladas.

KEY WORDS: Laennecia, Erigeron, Conyza, Astereae, Asteraceae, México, Chihuahua.

Intensive collecting by the second author in west central Chihuahua has brought to light a previously undescribed species of Laennecia. The new species proposed here joins Erigeron eriophyllus A. Gray, which occurs from southern Arizona to eastern Chihuahua, and an undescribed species (a narrow endemic from west central Chihuahua), to form a trio of related species restricted in distribution primarily to northwestern México. Transfer of $E$. eriophyllus to Laennecia, description of the other new species, and the taxonomy of Laennecia, along with the rationale for considering it as a genus separate from Conyza are presented in a separate paper (Nesom 1990). 
Laennecia pimana Nesom \& Laferrière, $s p$. nov. TYPE: MÉXICO. Chihuahua: Mpio. Temosachic, $1 \mathrm{~km}$ E of Nabogame, $28^{\circ} 30^{\prime} \mathrm{N}, 108^{\circ} 30^{\prime}$ W, pine-oak forest, $1800 \mathrm{~m}, 28$ Oct 1988, J.E. Laferrière 2216 (HOLOTYPE: TEX; Isotype: MEXU)

Erigeron eriophyllus A. Gray similis vestimento lanato eglanduloso, foliis non-amplecticaulibus, et acheniis costis crassis; differt a E. eriophyllus foliis integris, acheniis glandulosis sed aliter glabris, pappo manifeste biserialis et corollis pistillatis sine ligulis.

Short lived perennials $45 \mathrm{~cm}$ tall, from a taproot. Stems, leaves and phyllaries gray lanose, eglandular, upper leaf surfaces equally as pubescent as the lower. Leaves narrowly oblong, sessile, entire, $15-25 \mathrm{~mm}$ long, $2.5-4.0 \mathrm{~mm}$ wide, barely if at all reduced in size upward. Heads 6-7 mm wide (pressed), in a few headed, spike like panicle, on peduncles 5-15 mm long; phyllaries purplish, narrowly triangular, in 3-4 slightly graduated series, the innermost 6-7 $\mathrm{mm}$ long, the inner with a herbaceous midregion extending to the base or nearly so, the margins indurated-hyaline. Pistillate corollas $2.5-3.0 \mathrm{~mm}$ long, tubular-filiform, eligulate, apically fimbriate, much shorter than the style and style branches. Disc corollas slightly pubescent on the throat, eglandular, 4.3-5.0 $\mathrm{mm}$ long, the tube $3.0-3.5 \mathrm{~mm}$ long, ampliate immediately below the insertion of the lobes, the lobes $0.8-1.0 \mathrm{~mm}$ long, narrowly triangularlanceolate, spreading-recurved. Achenes obovate, 1.9-2.2 mm long, 0.8-1.0 $\mathrm{mm}$ wide, strongly flattened, the faces tan, glabrous except for a few, but prominent, sessile, resin glands near the apex, completely ringed by a thick, white rib; pappus of 33-39 slender, barbellate bristles 3.8-4.5 mm long, with an outer series of setae or bristles 0.3-0.5 mm long. Chromosome number unknown.

Known only from the type collection.

Laennecia pimana is named for the Mountain Pima inhabitants of the Sierra Madre. It is similar to Erigeron eriophyllus and the undescribed species in its lanose, eglandular vestiture, nonclasping leaves and thick ribbed achenes, but it is different from both in its eligulate pistillate corollas. It differs from E. eriophyllus in its entire leaves, apically glandular but otherwise glabrous achenes and prominently biseriate pappus. It differs from the undescribed species in its smaller achenes and pappus of fewer bristles.

The type locality is a mixed pine-oak forest dominated by Pinus engelmannii Carr., Quercus chihuahuensis Trel. and Q. viminea Trel. Typical plants of Erigeron eriophyllus (A. Gray) Nesom (Laferrière 1570, ARIZ) have been collected in the immediate vicinity. 


\section{ACKNOWLEDGMENTS}

We thank Drs. Billie Turner and Linda Escobar for their review and comments on the manuscript.

\section{LITERATURE CITED}

Nesom, G.L. 1990. Taxonomy of the genus Laennecia (Asteraceae: Astereae). Phytologia 68:205-228. 

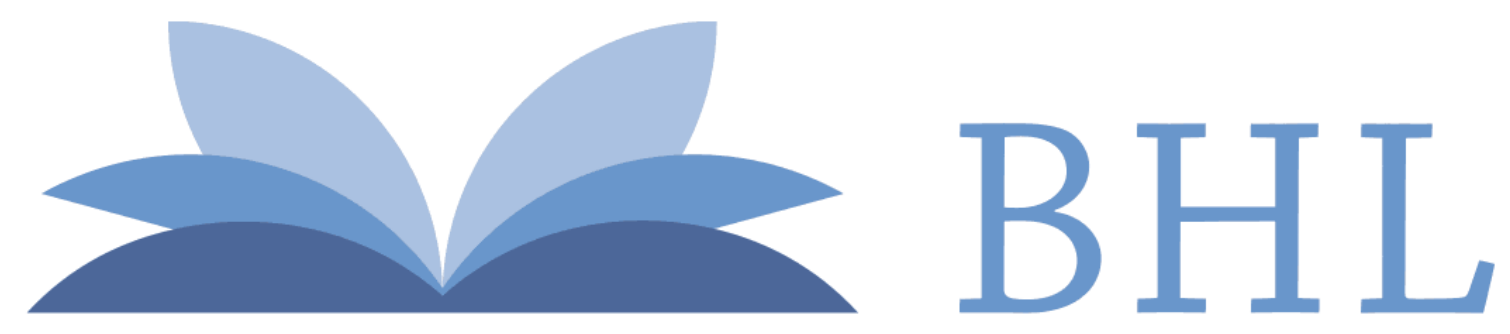

\section{Biodiversity Heritage Library}

Laferriére, J E and Nesom, G L. 1990. "A new species of Laennecia (Asteraceae: Astereae) from Chihuahua, México." Phytologia 68, 202-204. https://doi.org/10.5962/bhl.part.16710.

View This Item Online: $\underline{\text { https://www.biodiversitylibrary.org/item/46308 }}$

DOI: https://doi.org/10.5962/bhl.part.16710

Permalink: https://www.biodiversitylibrary.org/partpdf/16710

\section{Holding Institution}

New York Botanical Garden, LuEsther T. Mertz Library

\section{Sponsored by}

The LuEsther T Mertz Library, the New York Botanical Garden

\section{Copyright \& Reuse}

Copyright Status: In copyright. Digitized with the permission of the rights holder.

Rights Holder: Phytologia

License: http://creativecommons.org/licenses/by-nc-sa/3.0/

Rights: https://biodiversitylibrary.org/permissions

This document was created from content at the Biodiversity Heritage Library, the world's largest open access digital library for biodiversity literature and archives. Visit BHL at https://www.biodiversitylibrary.org. 